response was found between the two groups. The $\mathrm{I} / \mathrm{G}$ molar ratio, low during fasting, rose significantly after stimulation in both groups.

We have demonstrated that pancreatic endocrine activity is the same at birth in both SGA and AGA infants and is adequate to the metabolic state in neonatal life.

\section{REFERENCES AND NOTES}

1. Adams, P. A. J.: Control of glucose metabolism in the human fetus and the newborn infant. Advan. Metabol. Disord.. 5: 184 (1971)

2. Anthony, L. E., and Faloona, G. R.: Plasma insulin and glucagon levels in protein malnourished rats. Metabolism, 23: 303 (1974)

3. Assan, R.: In vivo metabolism of glucagon. In: P. J. Lefebvre and R. H. Unger: Glucagon, Vol. 47 (Pergamon Press, New York, 1972).

4. Cornblath, M., Wybregt, S.'H., Baens, G. S., and Klein, R. I.: Symptomatic neonatal hypoglycemia: Studies of carbohydrate metabolism in the newborn infants. Pediatrics, 33: 388 (1964).

5. Delamater, P. V., Sperling, M. A., Fiser R. M., Phelps D. L., Oh, W., and Fischer D. A.: Plasma alanine relation to plasma glucose, glucagon and insulin in the neonate. J. Pediat., 85: 702 (1974).

6. Exton, J. M.: Gluconeogenesis. Metabolism, 21: 945 (1972).

7. Falorni, A., Massi-Benedetti, F., Gallo, S., and Romizi, S.: Levels of glucose in blood and insulin in plasma and glucagon response to arginine infusion in low birth weight infants. Pediat. Res., 9: 55 (1975)

8. Falorni, A.. Massi-Benedetti, F., Gallo. S., and Trabalza, N.: Blood glucose. serum insulin, and glucagon response to arginine in premature infants. Biol. Neonate. 27: 271 (1975)

9. Hales, C. N., and Randle, P. J.: Immunoassay of insulin with insulin antibody precipitate. Biochem. J., 88: 137 (1963)

10. Leroy, B., and Lefort. F.: Courbes de croissance du nouveau-né et du prématuré Rev. Franç. Gynecol., 66: 391 (1971).

11. Lubchenko, L. O.. and Bard, H.: Incidence of hypoglycemia in newborn infants classified by birth weight an gestational age. Pediatrics, 47: 831 (1971).

12. Luyck, A. S., Massi-Benedetti, F., Falorni, A., and Lefebvre, P. J.: Presence of pancreatic glucagon in the portal plasma of human neonates: Differences of insulin and glucagon response to glucose between normal infants and infants of diabetic mothers. Diabetologia, 8: 296 (1972)

13. Massi-Benedetti, F., Falorni, A., Luyck, A., and Lefebvre. P. J.: Inhibition of glucagon secretion in the human newborns by simultaneous administration of glucose insulin. Hormone Metabol. Res. 6: 392 (1974).

14. Milner, R. D. G.. Chouksey, S. K.. Micklesow, K. N. P.. and Assan, R. Plasma pancreatic glucagon and insulin glucagon ratio at birth. Arch. Dis. Childhood, 49: 241 (1973).

Copyright (1) 1977 International Pediatric Research Foundation, Inc.
15. Neligan, G. A., Robson, E., and Watson, J.: Hypoglycemia in the newborn, a sequel of intrauterine malnutrition. Lancet, $i$ : 1282 (1963)

16. Reissner, S. N., Aranda, J, V., Colle, E., Papageorgiou, A.. Schiff, D., Scriver, C. R., and Stern, L: The effect of intravenous glucagon on amino acids in the newborn. Pediat. Res., 7: 184 (1973).

17. Ruiton-Ugliengo, A., and Frederich, F.: Dosage radio-immunologique spécifique du glucagon pancréatique: Applications chez le nouveau-né et leenfant. Diabète Métabol., 1: 143 (1975).

18. Salle, B., Chance, G. W., and Ruiton-Ugliengo, A.: In: J. Stetson and P. R. Swyer: Neonatal Intensive Care, p. 165 (Warren H. Green, St Louis, Mo.. $1900)$.

19. Salle, B., and Ruiton-Ugliengo, A.: Glucose disappearance rate, insulin response and growth hormone response in the small for gestational age and premature infants of very low birth weight. Biol. Neonate, 29: 1 (1975)

20. Samols, J. K.. Tyler, J. M., and Marks, V.: Glucagon-insulin interrelationships. In: P. J. Lefebvre and R. H. Unger: Glucagon, Vol. 151 (Pergamon Press, New York, 1972).

21. Sperling, M. A., Delamater, P. V., Phelps, D., Fiser, R. J. R., Oh, W., and Fischer, D. A.: Spontaneous and amino-acid stimulated glucagon secretion in the intermediate post-natal period: Relation to glucose and insulin. J. Clin. Invest. 53: 1159 (1974).

22. Unger, R. H.: Glucagon physiology and pathophysiology. N. Engl. J. Med., 285: 443 (1971).

23. Unger, R. H.: Alpha and beta cell interrelationships in health and disease. Metabolism, 23: 581 (1974)

24. Unger. R. H., and Lefebvre, P. J.: Glucagon physiology. In: P. J. Lefebvre and R. H. Unger, Glucagon, Vol. 47 (Pergamon Press, New York, 1972).

25. Williams, P. R. Fiser, R. H. Sperling, M. A., and Oh, W. Effects of oral alanine feeding on blood glucose, plasma glucagon and insulin concentrations in small for gestational age infants. N. Engl. J. Med., 292: 612 (1975).

26. Wise, J. K., Lyall, S. S., Hendler, R., and Felig, P.: Evidence of stimulation for glucagon secretion by alanine in the human fetus at term. J. Clin. Endocrinol. Metabol., 37: 345 (1973).

27. Monsieur Biron. Départment d'Informatique, Hospices Civils de Lyon.

28. Informed consent was obtained from the parents so that their infants could be included in this study.

29. The authors wish to express their appreciation for advice and for the translation of Professor P. R. Swyer (Toronto), for the study of results of Professor Bertrand (Inserm, Lyon), for the technical help of Mrs F. Frederich and Mrs. Viand, and for the secretarial assistance of Miss M. Pastor.

30. The present address of Dr. A. Ruiton-Ugliengo is: Unité Inserm U.34 (Professor Bertrand) Hopital Debrousse, 69(7)5 Lyon (France).

31. Requests for reprints should be addressed to: B. L. Salle, M.D., Neonatal Department, Hopital Edouard Herriot, 69374 Lyon Cedex 2 (France).

32. Received for publication March 2, 1976.

33. Accepted for publication August 6. 1976

Pediat. Res. 11: 112-116 (1977)

Calcitonin magnesium

calcium

growth

Printed in U.S.A

\title{
Serum Calcitonin and Blood Mineral Interrelationships in Normal Children Aged Six to Twelve Years
}

\author{
RUTH SHAINKIN-KERSTENBAUM, BRURIA FUNKFNSTFIN, AVIVA CONFORTI, SHRAGA \\ SHANI, AND GEOFFREY M. BERLYNE(23) \\ Department of Nephrology and Toor Institute of Medical Re'search, Soroka University Hospital, Beersheba, Israel
}

\section{Summary}

Simultaneous measurements of serum immunoreactive thyrocalcitonin (iTCT), immunoreactive parathyroid hormone (iPTH), calcium, inorganic phosphate, magnesium, and alkaline phosphatase were made in 37 normal children whose ages ranged from 6-12 years. Between the ages of 6 and 12 there is a statistically significant rise in serum iTCT levels $(r=0.4638 ; P$ $<0.01)$, and a fall in serum iPTH levels $(r=0.4976 ; P<0.01)$. There is a highly significant inverse correlation between serum iTCT and iPTH levels $(r=0.5248 ; P<0.005)$. Serum iTCT levels were inversely correlated with phosphate levels $(r=$ $0.4989 ; P<0.01)$, the latter being age dependent and falling significantly between the ages of 6 and $12(r=0.4802 ; P<$ 
0.001). There was no significant relationship between serum calcium levels and iTCT, iPTH, or age. Serum magnesium levels were not correlated with calcium, iTCT, or iPTH levels.

\section{Speculation}

Serum iTCT is important in the growth process, particularly in the steady growth towards the end of childhood, and the inverse relationship between iTCT and $\mathrm{iPTH}$ levels suggests that a dual control mechanism exists which is capable of striking the fine balance between bone anabolism and catabolism necessary for normal skeletal growth.

In childhood serum phosphorus and calcium levels are higher than in adults, and serum iPth levels are lower between the ages of 6 and 12 than in adults $(3,14,16)$. There is little published work on serum il (T levels in children, and because of the accumulated evidence of the importance of $T(\mathrm{~T}$ in the process of accretion of bone mineral $(1,5,10,11,13)$, it was decided to investigate serum ill ("I levels in growing. normal children between the ages of 6 and 12, and to correlate them with other factors of known importance in skeletal metabolism: iPTH, calcium, magnesium, phosphorus, and alkaline phosphatasc.

\section{ANALYTIC METHODS}

Venous blood was drawn without stasis from nornal children living in Kibbutz Yotvatah in the Aravah Rift Valley of lsrael who had volunteered for a survey of plasma fluoride levels and divalent ion studies before a change of water supply to a reverse osmosis system. Adults in the same kibbutz. were the control group. The children were between the ages of 6 and 12 . The blood samples were taken in the forenoon, in the fasting state, in the height of summer. The blood was placed in a refrigerator at $4^{\circ}$, allowed to clot for $1 \mathrm{yr}$, and separated at $4^{\circ}$. All the tubes were made of flint glass. The blood was then frozen at $-20^{\circ}$ in several flint glass tubes for each subject and subsequently thawed once for each test. All samples for se rum ill'I and iP TH assay, respectively. were examined simultaneously with a detailed standard curve being made at the beginning of the test. Standards were also included in each rack of tubes used in the radioimmunoassay. Human synthetic calcitonin (Ciba) and rabbit antiserum to human calcitonin were kindly donated by Dr. Asher Haymovitz. Rockefeller University, New York, and the radioimmunoassay (RIA) for serum il (T levels was carricd out as follows.

A noncyuilibrium svstem was used in $0.1 \mathrm{M}$ phosphate buffer at $\mathrm{pH} 7.5$. Serum samples of $100 \mu \mathrm{l}$ and $250 \mu \mathrm{l}$ were incubated with $100 \mu \mathrm{l}$ antibody solution in buffer containing $0.25 \%$ human serum albumin. Serum samples without antibody served as controls. The reaction mixture was brought to a final volume of 0.6 $\mathrm{ml}$ with buffer. After $24 \mathrm{hr}$ of preincubation at $4^{\circ} .100 \mu \mathrm{l}$ (about $2,000 \mathrm{cmm}$ ) of labeled calcitonin (freshly labeled or within 2 weeks of labeling. having been kept frozen at $-20^{\circ}$ ) was added to the reaction mixture. Tubes were kept at $4^{\circ}$ for another $24 \mathrm{hr}$. Separation of bound from free hormone was made using dextran-coated charcoal by the method of Herbert (8), with a modification in the charcoal and dextran concentration to a final concentration of $1 \%$ charcoal. $0.25 \%$ dextran 70 in $0.35 \%$ human serum albumin. After adding the charcoal suspension, tubes were kept at $4^{\circ}$ for $40 \mathrm{~min}$ to reach equilibrium and then were entrifuged. Both supernatant and precipitate radioactivity were measured in a Packard automated gamma counter.

A standard curve was made using the same procedure except that each tube contained $100 \mu$ l hypocalcitonic serum obtained from a patient who had undergone total thyroidectomy some years earlier; this was used to compensate for nonspecific interference caused by serum. (urves which contained $100 \mu \mathrm{l}$ or 250 $\mu l$ hypocalcitonic serum were identical so that the same curve could serve for both volumes of test serum used.

Labeling of calcitonin was performed using 12:5 by the method of Hunter and Greenwood (9) with the following modification: oxidation with $20 \mu \mathrm{l}$ of chloramine $\mathrm{T}$ for $30 \mathrm{sec}$ : separation of [12.5 I] calcitonin from free ${ }^{125}$ I was performed by absorption on QUSO (18) and washing twice with water to remove free 1 The labeled hormone was extracted from QUSO with an acid solution containing $0.25 \%$ acetone in $20 \%$ acetic acid.

The coefficient of variation of replicate determinations was $3.2 \%$. The lower limit of sensitivity of the assay for iTC $\mathrm{T}$ was

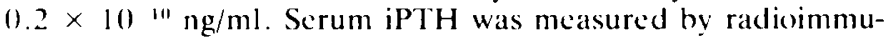
noassay (2) using highly purified bovine PTH and guinea pig antiserum to bovine PTH (19).

The method of Arnaud (2) was used for radioimmunoassay with the following modifications: $100 \mu \mathrm{l}$ and $200 \mu \mathrm{l}$ serum were incubated with $100 \mu \mathrm{l}$ antibody solution, the volume being brought to $0.6 \mathrm{ml}$ with barbital saline buffer, $0.05 \mathrm{MpH} 7.4$. containing $100 \mathrm{U} / \mathrm{ml}$ of Tracylol. After 3 days of preincubation at $4^{\circ} .100 \mu \mathrm{l}$ labeled [12i IPTH (i.e., approximately $\left.2.000 \mathrm{cpm}\right)$ were added and the reaction mixture was kept at $4^{\circ}$ for 4 more days. The reaction was stopped by adding dextran-coated charcoal as described above.

A standard curve was made by adding to each tube $100 \mu \mathrm{l}$ of hypoparathyroid serum (taken from a patient after total thyroparathyroidectomy or after suppressing immunoreactive PTH by (a infusion in a volunteer) as a control for nonspecific interference caused by serum.

Labeling of PTH was done according to the method of Hunter and Greenwood (9) with the following modification: $60 \mathrm{\mu l}$ chloramine $T$ were used for $15 \mathrm{sec}$ with termination of the reaction with $4.8 \mu \mathrm{l}$ of sodium metabisulfite. [2.5 I]PTH was absorbed on QUSO and washed twice with water to separate free ${ }^{12 .}$. Labeled PTH was eluated from QUSO in acid solution and purified immediately before use on a Bio-Gel $\mathrm{P}-100$ column (20) with elution using an eluent consisting of $\mathrm{HCl}$ in saline solution, $\mathrm{pH} 3.2$, containing $0.1 \%$ human serum albumin.

Only two or three tubes of the eluate taken from the peak of the pure labeled PTH material were used as a tracer in the subsequent RIA system. The coefficient of variation of replicate determinations was $6.3 \%$. The lower limit of sensitivity for determination of iPTH was $0.3 \times 10^{-y} \mathrm{~g} / \mathrm{ml}$. Plasma levels of 25 hydroxycholecalciferol $(25-\mathrm{HCC})$ were measured by a protein competitive binding technique (7).

Serum calcium and magnesium were measured on a Varian atomic absorption spectrophotometer model 1200; inorganic phosphate and alkaline phosphatase were measured on an Autoanalyzer by standard Technicon methods. Results were analyzed by the Student $t$-test and the linear correlation coefficient was determined on a Hewlett-Pack ard calculator, model HP 6.5, with Hewlett-Packard programs.

\section{RESULTS}

There were 22 male and 1.3 female children in the group examined. All were of Ashkenazi Jewish extraction.

Serum iTC levels increased from $0.6 \times 10^{\prime \prime \prime} \mathrm{g} / \mathrm{ml}$ at age $6 \mathrm{to}$ a mean of $3.9 \times 10^{10} \mathrm{~g} / \mathrm{ml}$ at age 12 . Serum iTC $\mathrm{T}$ increases significantly with age (see Fig. 1),$r=0.51273 ; P<0.01$; serum iP'TH falls from 2.9 at age 6 to a mean of 1.1 at age 12 . There is a significant inverse correlation between serum iPTH levels and age $(r=0.4673 ; P<0.01)$ (Fig. 2).

Serum iTC 1 and iPTH levels are highly significantly inversely correlated $(r=0.5621 ; P<0.001)$ (Fig. 3). (It is possible that the correlation is curvilinear but this has not been statistically evaluated in this paper, linear correlation having been found to be highly significant.) Serum iT( $T$ levels are not related to scrum calcium $(r=0.3438: P<0.05)$. magnesium $(r=$ $0.0418 ; P<0.03)$, or alkaline phosphatase $(r=0.3790 ; P$ $<0.05)$. However, there is a significant inverse correlation 


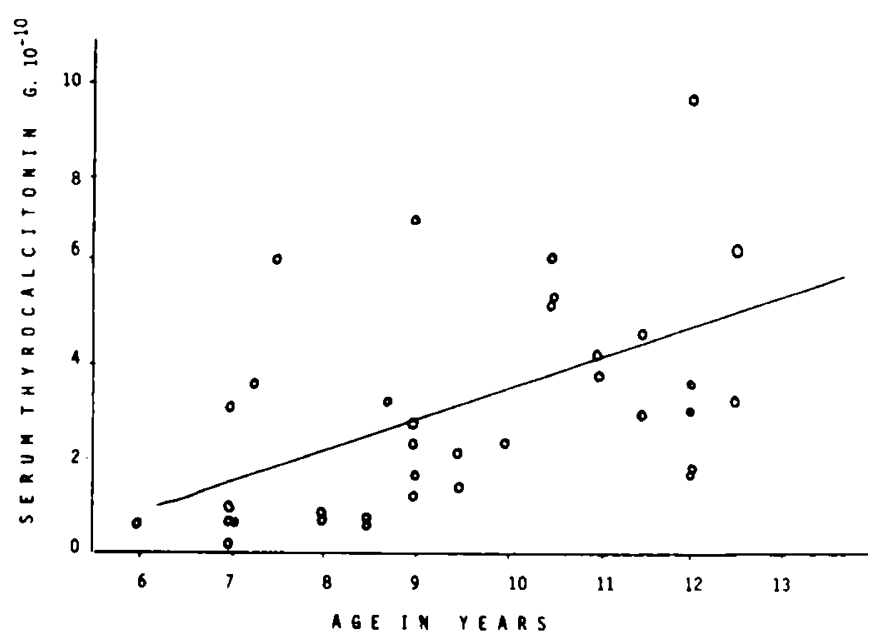

Fig. 1. Relationship between serum immunoreactive thyrocalcitonin and age in years $(r=0.51273 ; P<0.01)$.

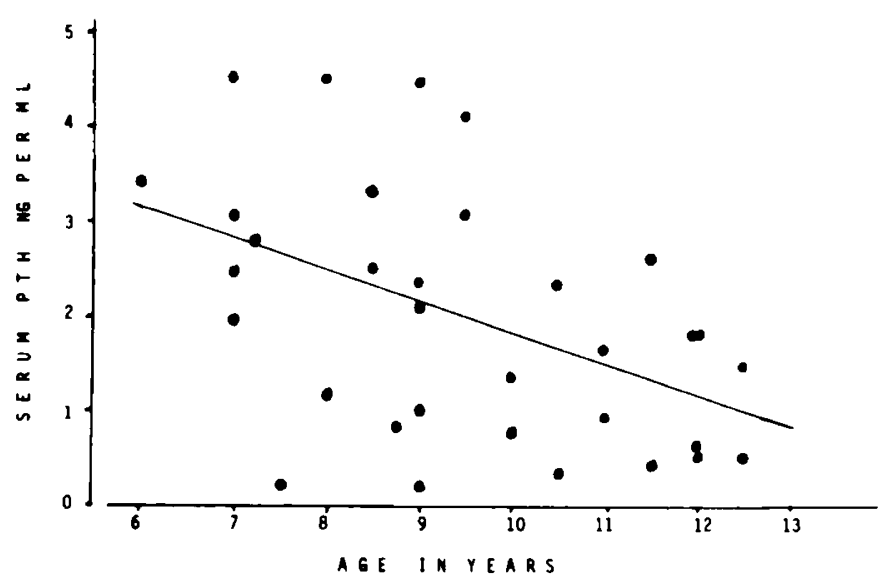

Fig. 2. Relationship between serum immunoreactive parathyroid hormone $(P T H)$ levels and age $(r=0.4673 ; P<0.01)$

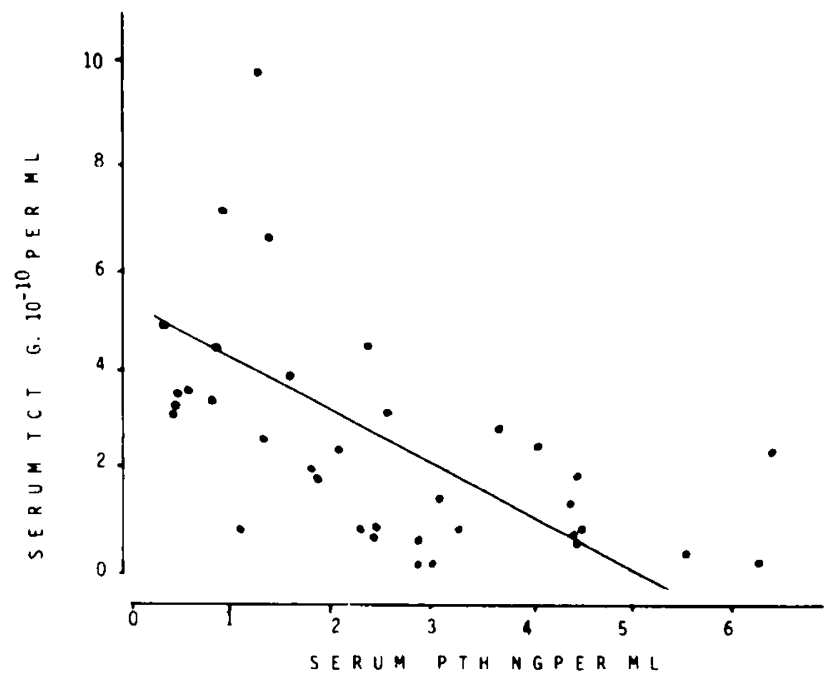

Fig. 3. Relationship between serum immunoreactive thyrocalcitonin $(T C T)$ and immunoreactive parathyroid hormone $(P T H)$ levels $(r=$ $0.5621 ; P<0.0(11)$.

between serum iTe'l levels and phosphate $(r=0.4268 ; P<$ (0.05). Serum phosphate levels are inversely correlated with age $(r=0.48327 ; P<0.01)$ (Fig. 4). Serum iPTH levels are not significantly correlated with serum calcium levels $(r=0.00014$; $P<0.2)$ or serum magnesium levels $(r=0 .(1804 ; P<0.1)$, but

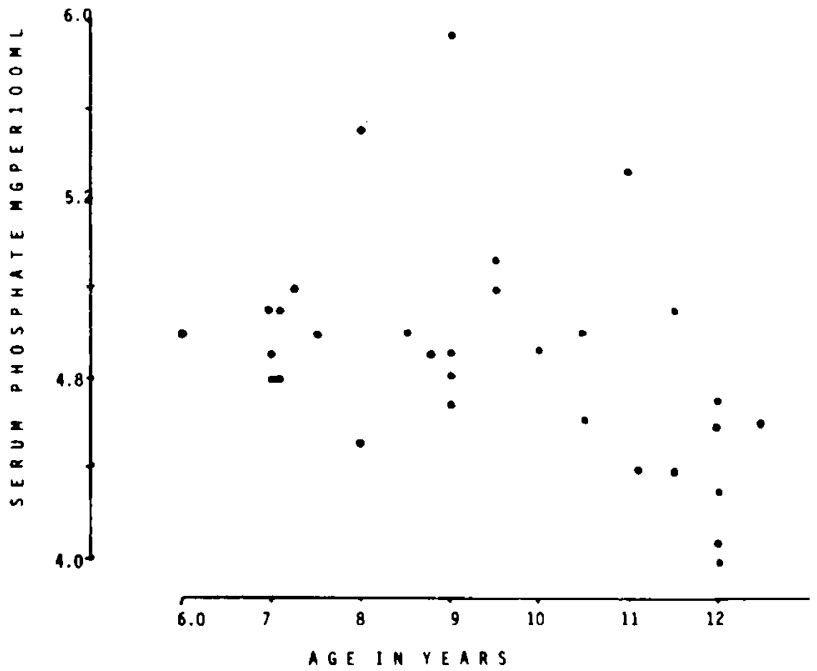

Fig. 4. Relationship of serum phosphate levels correlated with age ( $r$ $=0.48327 ; P<0.01)$.

are significantly correlated with serum and phosphate $(r=$ $0.4074 ; P<0.05)$ and serum alkaline phosphatase levels $(r=$ $0.39395 ; P<0.05)$.

In Table I the results are presented of serum TC" HCC, calcium, magnesium, phosphate, and alkaline phosphatase levels in adults compared with the mean in the 6-12-yearold age group. PTH, 25-HC', calcium, magnesium, phosphate, and alkaline phosphatase levels are significantly higher in children, but the T( T level was not significantly different in children and in adults. In Table 2 the mean values of serum PTH and iTC T levels are presented in patients grouped according to sex. There are no significant differences between the series with regard to the serum concentrations of iPTH and $I T C T$.

\section{DISC USSION}

There is little published work on calcitonin levels in childhood after the neonatal period (12) and we have only been able to find onc paper in which calcitonin levels in the 6-12-ycar-old group are recorded (14). They found that, in 6.5 normal children between the ages of 5 and $10.24 \%$ had levels of ealcitonin greater than the upper limit of normal in their laboratory for adults of $\mathrm{I} \mathrm{ng} / \mathrm{ml}$. In the course of a study embracing childhood and adolescence they found that calcitonin levels fell from a mean of about $5 \mathrm{ng} / \mathrm{ml}$ in the first $24 \mathrm{hr}$ of life to about $1.5 \mathrm{ng} / \mathrm{ml}$ in the 1 -month to 5 -year-old age group, and a mean of $1 \mathrm{ng} / \mathrm{ml}$ in the 5-10-year-old age group. We found normal adults to be in the same range as found by others $(14,16)$, i.e., below $1 \mathrm{ng} / \mathrm{ml}$. However, in the group of 6-12-year-old children there was a significant age-dependent rise in calcitonin levels, frequently above the levels found in adults. The mean iTC"I level of the entire age group was found, however, to be not significantly different from that in adults. The difference between our findings and those of Samaan and colleagues (14) may be explained as follows: our study presents individual results with age dependence in detail in the 6-12-year age group, whereas they published only the means of several large age groups, concentrating on the difference between the various age groups: $i . e^{\prime}$., neonates; 1 month-5-years; 5-10 years; $10-20$ years; 21-60 years. This method of presentation does not reveal whether the individual results in any one age group showed age dependence when considered within the specific group itself. Our finding of a calcitonin level which was age dependent; $i$.e., increasing as the upper end of the age group was approached, is new. It was also shown that PTH levels fall as the age rises from 6-12, and that both PTH and T(T levels are highly significantly correlated. There was no relationship between serum calcium levels and serum P'IH or TC"I levels; this agrees with the finding of Arnaud et al. (3), who pointed out that serum PТH levels are not 
Table 1. (omparison of mean serum levels of immunoreactive thyrocalcitonin (iTC $T$ ), immunoreactive parathyroid hormone (iPTH), 25-hydroxycholecaliferol (25-HC('), calcium, magnesium, phosphate, and alkaline phosphatase (Alk-Pase) in children aged 6-12 and

\begin{tabular}{|c|c|c|c|c|c|c|c|}
\hline \multirow{3}{*}{ 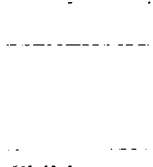 } & \multirow[b]{3}{*}{ ilC"l, $10^{111} \mathrm{~g} / \mathrm{ml}$} & \multirow[b]{3}{*}{$\mathrm{iPlH}, \mathrm{ng} / \mathrm{ml}$} & \multicolumn{2}{|c|}{ in adults } & \multirow[b]{2}{*}{$\mathrm{Mg}$} & \multirow[b]{2}{*}{$\mathbf{P}$} & \multirow{3}{*}{$\begin{array}{c}\text { Alk-Pase, KA } \\
\text { units/100 ml }\end{array}$} \\
\hline & & & & $\mathrm{Ca}$ & & & \\
\hline & & & $25-\mathrm{HCC}, \mathrm{ng} / \mathrm{ml}$ & & $\mathrm{mg} / 100 \mathrm{ml}$ & & \\
\hline \multicolumn{8}{|c|}{ Children } \\
\hline$n$ & 37 & 32 & 18 & 32 & 32 & 31 & 27 \\
\hline $\bar{x}$ & 3.22 & 1.98 & 6.3 .40 & 10.17 & 1.77 & 4.48 & $2.5 .0(0)$ \\
\hline SD & 2.21 & 1.30 & 15.26 & 1.07 & 0.16 & \pm 0.51 & 5.86 \\
\hline Range & $0.2-9.8$ & & & & & & \\
\hline \multicolumn{8}{|l|}{ Adults } \\
\hline$n$ & 30 & 31 & 26 & 30 & 30 & 30 & 30 \\
\hline $\bar{x}$ & 2.66 & 0.84 & 46.94 & 9.71 & 1.67 & 3.69 & 7.54 \\
\hline $\mathrm{SD}$ & 1.33 & 0.592 & 16.67 & 0.56 & 0.24 & 0.39 & 5.02 \\
\hline Range & $0.2-5.4$ & & & & & & \\
\hline$t$ & 1.22397 & 4.4355 & 3.332 & 2.0813 & 1.8268 & 6.771 & 12.0734 \\
\hline $\mathrm{df}^{\prime}$ & 6.5 & 61 & 42 & 60 & 60 & 59 & 55 \\
\hline$P$ & $>0.10$ & $<0.00005$ & $<0.00(12.5$ & $<0.025$ & $<0.05$ & $<0.0005$ & $<0.00005$ \\
\hline
\end{tabular}

Degrees of freedom.

Table 2. Effect of sex of children on immunoreactive parathyroid hormonc (iPTH) and immunoreactive throcalcitomin (iTC $T$ ) levels

\begin{tabular}{|c|c|c|c|c|}
\hline & \multicolumn{2}{|c|}{ Plasma iPTH, $\mathrm{ng} / \mathrm{ml}$} & \multicolumn{2}{|c|}{ Plasma iTCT, $10^{\prime \prime \prime} \mathrm{g} / \mathrm{ml}$} \\
\hline & Males & Females & Males & Females \\
\hline No. & 20 & 13 & 22 & 13 \\
\hline Mean & 1.78 & 1.98 & 3.27 & 3.33 \\
\hline SD & \pm 1.31 & \pm 1.13 & \pm 1.81 & \pm 3.2 \\
\hline
\end{tabular}

correlated with serum total calcium levels, but are correlated with serum ionized calcium levels. Unfortunately, the design of the experiment in the field $250 \mathrm{~km}$ south of this laboratory did not permit the measurement of ionized calcium. On the other hand, the serum phosphate level is significantly inversely correlated with age $(P<0.01)$, inversely with serum TCT $(P<$ 0.01), and directly with serum PTH levels $(P<0.05)$, and this may indicate a fairly complex interrelationship between PTH. TC $\mathrm{T}$, and phosphate in this age group. The role of ionized calcium must remain speculative in the absence of data. Serum magnesium level was not related to PTH or TCT levels, although it was significantly higher in this age group than in adults.

Increasing levels of TCT and falling levels of PTH may favor mineral accretion in the bone $(1,5)$ and so contribute to the mineralization needed for growth of bone in this age group. The correlation between serum TC $T$ ' and PTH levels is highly significant $(P<0.001)$, and this is possibly mediated by ionized calcium levels.

Arnaud et al. (3) found in children of the United States a higher serum phosphate value in the 6-12 age group than we found in Israeli children. This may be a reflection of the lower protein and phosphate intake in Israclis.

We did not observe an age-dependent increase of alkaline phosphatase in children between 6 and 12 years, but the mean value is significantly higher than that found in adults.

There are no available data for normal growth velocity in Israeli children and therefore, the figures of Falkner (4) were used, although their relevance is dubious since they refer to growth rates of children in the United States. There was no significant correlation between the velocity of height growth and TCT levels.

The active vitamin D metabolites, 1.25-dihydroxycholecalciferol and 1,24,25-trihydroxycholecalciferol, were not measured in these children. Measurements of $25-\mathrm{HCC}$ in the older children were made and were all high as would be expected in children playing in an area of high intensity ultraviolet light with cloudless skies. They were also significantly higher than the results found in adults. This may be because children spend more of their time with their skin exposed to the sun, e.g., at the swimming pool, than adults, but this must remain speculation. Consequently, the interaction between TC'T. P'TH, and the most active vitamin $D$ metabolities remains to be explored in children of this age group. Our groups were remarkably uniform with regard to conditions of life-dict, social and ethnic groups, sunlight exposure; all were healthy; all blood samples were taken on the same day at the height of summer. In contrast, Arnaud's groups were markedly less uniform. They included both white and black children, there was a 2-year period of collection of samples, and the children were all sick. It may be suggested that our results are, therefore, possibly more reliable in indicating the changes with age in healthy children in this age group.

\section{CONCLUSION}

In children from age $6-12$ years, there is an increase in plasma calcitonin levels and a decrease in plasma parathyroid hormone levels.

\section{REFERENCES AND NOTES}

1. Alcapoulios, M. A.. Goldhaber, P.. and Munson, P. L.: Thyrocalcitonin inhibitions of bone resorption induced by PTH in tissue culture. Science. 151: $331(1966)$

2. Arnaud, C. D., Tsao, H. S., and Littledike, T.: The radio-immunoassay of human parathyroid hormone in serum. J. Clin. Invest.. 50: 21 (1971)

3. Arnaud, S. B., Goldsmith. R. S., Stickler, G. B., McCall, J. T. . and Arnaud, C. D.: Serum parathyroid hormone and blood minerals interrelationships in normal children. Pediat. Res., 7: 485 (1973).

4. Falkner, F.: Some physical growth standards for white North American children. Pediatrics, 29: 467 (1962)

5. Friedman, J.. and Raisz, L. G.: Thyrocalcitonin: Inhibitor of bone reabsorption in tissue culture. Science, 150: 1465 (196.5)

6. Gray, T. K., Bieterdorf. F. A., and Fordtran, J. S.: Thyrocalcitonin and the jejunal absorption of calcium. water and electrolytes in normal subject. J. Clin. Invest., 52: 3084 (1973)

7. Haddad, J. H.. and Chyu, K. J.: Competitive protein radioassay for 25 hydroxycholecalciferol. J. Clin. Endocrinol. 33: 992 (1971).

8. Herbert, V. K. S. Lau. C. W., and Gotlicb, S. J.: Coated charcoal innumoassay of insulin. J. Clin. Endocrinol. Metab., 25: 1375 (1962).

9. Hunter, W. M. and Greenwood, F. C.: Preparation of iodine 1.31 labelled human growth hormone of high specific activity. Nature 194: 495 (1962).

10. Holtrop, M. E., Raisz. L. G., and Simmons, H. A.: The effects of parathyroid hormone, colihicine and calcitonin on the ultrastructure and the activity of osteoclasts in organ culture. J. Cell Biol.. 60: 346 (1974)

11. O'Riordan, J. L. H., and Aurbach, G. D.: Mode of action of thyrocalcitonin. Endocrinology, 82: 377 (1968).

12. Pitkin, R. Y.: Calcium metabolism in pregnancy: A review. Amer. J. Obstet Gynecol.. 121: 724 (1975).

13. Queener, S. F., and Bell, N. H.: Calcitonin: A general survey. Metabolism. 24: $555(1975)$.

14. Samaan, N. A.. Anderson. G. D., and Adam-Mayne, M. E. Immunoreactive 
calcitonin in the mother, neonate, child, and adult. Amer. J. Obstet. Gynecol., 121: 622m (1975)

15. Shearns, G., and Warweg. E.: Studies of phosphorus of blood. 1. The partition of phosphorus in whole blood and serum. The serum calcium and plasma phosphatase from birth to maturity. J. Biol. Chem., 102: 749 (1933).

16. Tashjian, A. H., Howland, B. G., Melvin, K. W., and Hill, C. S., Jr Immunoassay of human calcitonin. N. Engl. J. Med., 283: 890 (197()).

17. Widdowson, E. M., and Dickerson, J. W. T.: Chemical composition of the body. In: C. L. Comar and F. Bronner: Mineral Metabolism: An Advanced Treatise, Vol. 2. Part A, p. 128 (Academic Press, New York, 1964).

18. Philadelphia Quartz Co., Philadelphia, Pa

19. A gift from Dr. G. Lumb, Manchester Royal Infirmary, Mannheim, England
20. Bio-Rad Laboratory, Richmond, Cal.

21. Informed consent was obtained from all the subjects and their parents who took part in this study.

22. G. M. Berlyne is an established Investigator of tile Chief Scientist's Bureau, Israel Ministry of Health, supported in part by grants from the United States-Israel Binational Fund and the Israel Ministry of Health.

23. Requests for reprints should be addressed to: G. M. Berlyne, M.D., Professor of Medicine, State University of New York, Chief, Renal Section, Brooklyn Veterans Administration Hospital, 800 Poly Place, Brooklyn, N. Y. 11209 (USA).

24. Received for publication April 19, 1976.

25. Accepted for publication August 6, 1976

\title{
Absence of Placental Transfer of L-Triiodothyronine $\left(\mathbf{T}_{3}\right)$ in the Rat
}

\author{
J. D. Dubois, A. Cloutier, P. WALKeR, AND J. H. DusSaulT ${ }^{13}$
}

Service d'Endocrinologie-Métabolisme, Le Centre Hospitalier de l'Université Laval, Quebec, Canada

\begin{abstract}
Summary
To detect placental transfer of $L$-triiodothyronine $\left(T_{3}\right)$ in pregnant rats, we injected $\left.1 \mu \mathrm{Ci}\left[{ }^{125}\right]\right] \mathrm{T}_{3}$ on the 16th, 18th, and 20th day of gestation. Three hours after the injection, which corresponds to the equilibrium time determined by a method of constant infusion, the pregnant rats and their fetuses were killed. The $\left[{ }^{125} I\right] T_{3}$ was extracted from the serum or the homogenate by butanol extractions and alkaline washes. The transfer rate was calculated from the quantity of $\left[^{125} I\right] T_{3}$ in the serum of the fetuses after $3 \mathrm{hr}$ and from the maternal metabolic clearance rate $(8.19 \pm 0.45 \mathrm{ml} / \mathrm{hr} / 100 \mathrm{~g}$ body weight; mean $\pm \mathrm{SEM})$. At the 16th day of gestation, the placental transfer of $T_{3}$ was $0.82 \pm$ $0.11 \%$ of the total maternal clearance rate/litter weight; it was $1.05 \pm 0.25 \%$ at the 18 th day of gestation and $0.58 \pm 0.10 \%$ at the 20th day of gestation. There were no significant differences between these results. The maternal $T_{3}$ concentration was 68.27 $\pm 20.6 \mathrm{ng} / 100 \mathrm{ml}$ and its production rate was $5.57 \pm 0.31 \mathrm{ng} / \mathrm{hr} /$ $100 \mathrm{~g}$; with these data we calculated a maternal-fetal $T_{3}$ transfer of $46 \pm 6 \mathrm{pg} / \mathrm{hr}$. Furthermore, there was no $T_{3}$ transfer observed when the mother received $1.9 \mu \mathrm{g}$ unlabeled $T_{3}$, which led to a significant rise in maternal $T_{3}$ concentration $(68.27 \pm 20.6 \mathrm{ng}$ to $102.23 \pm 7.41 \mathrm{ng} / 100 \mathrm{ml} ; P<0.01)$; there was no detectable $T_{3}$ in the fetal serum. From these results we conclude that there is minimal or no placental transfer of $T_{3}$ in the rat and that the hypothalamic-pituitary-thyroid axis of the fetus develops autonomously.
\end{abstract}

\section{Speculation}

The present data plus the fact that the rats are hypothyroid at birth support the concept of an autonomous development of the hypothalamic-pituitary-thyroid axis. It suggests that the rat can serve as a useful model for development of this axis in the human.

Studies in the sheep (7) and guinea pig (11) have shown that the maternal-fetal placental passage of L-triiodothyronine $\left(\mathrm{T}_{3}\right)$ is minimal, and that the fetal hypothalamic-pituitary-thyroid axis develops autonomously. However, no clear evidence is available for the autonomy of the fetal hypothalamic-pituitary-thyroid axis in the rat, a species in which this ontogenetic maturation occurs during the neonatal period (3).

Many authors have previously reported studies of placental transfer of thyroxine $\left(T_{4}\right)$ and $T_{3}$ in pregnant rats. Some reported a passage of $T_{4}$ and $T_{3}$ through the placenta $(9,10)$, whereas others concluded that $T_{4}$ and $T_{3}$ could not reach the fetus $(4,13)$.

The methods utilized by these authors were indirect methods which were more qualitative than quantitative. They did not measure quantitatively the $T_{3}$ or $T_{4}$ which reached the fetus.

In order to study placental transfer of $T_{3}$ we examined $T_{3}$ kinetics in order to ascertain the presence or absence of placental transfer of $T_{3}$ in the rat.

\section{MATERIALS AND METHODS}

Virgin Sprague-Dawley rats $(150-200 \mathrm{~g})$ were mated at the supply house (15) and shipped 2 weeks after mating. Pregnant animals were kept in separate cages in a sound-attenuated and temperature- and light-controlled room $\left(24 \pm 1^{\circ} ; 10 \mathrm{hr}\right.$ of darkness, $14 \mathrm{hr}$ of light) and had free access to rat laboratory chow and water.

\section{EQUILIBRIUM TIME}

The equilibrium time of $T_{33}$ for pregnant rats was calculated by a method of constant infusion. Purified $\left.\right|^{12.5} \mathrm{I} \mid \mathrm{T}_{3}\left({ }^{4} \mu \mathrm{C} \mathrm{i} / \mathrm{hr}\right.$, specific activity: $475 \mu(\mathrm{i} / \mu \mathrm{g})$ was injected through an indwelling jugular camnula for $3 \mathrm{hr}$ at a rate of $1.0 \mathrm{cc} / \mathrm{hr}$ using a model 355 syringe pump from Sage Instruments.

Blood, $0.5 \mathrm{ml}$, was collected through a carotid cannula at 0 , $15,30,45,60,90,120$, and $180 \mathrm{~min}$ after the infusion onset and replaced with an equivalent volume of $0.9 \% \mathrm{NaCl}$. The blood samples were centrifuged and the serum was frozen $\left(-20^{\circ}\right)$ until extraction. The butanol extraction was performed in duplicates 